\title{
Elementary School Teachers' Readiness in The Implementation of Full-Day School Program in Gorontalo Regency
}

\author{
Gamar Abdullah \\ Lecturer in the Department of Elementary Teacher Education, Faculty of Educational Studies, Gorontalo State University \\ Corresponding e-mail: gamar.pgsdung@gmail.com
}

\begin{abstract}
Education in elementary school is a determining factor to produce students with good characters and morality. Recently, the dynamics of Indonesian education is significantly changing. This change ranges from the advancement of science and technology to curriculum shifting, and, to the most recent controversial full-day school program. This descriptive research aims at describing elementary school teachers' readiness in the implementation of full-day school. The sample is from 100 elementary school teachers from a number of schools in some sub-district in Gorontalo regency. Each is chosen randomly and entirely by chance. The indicators of this research are (1) teachers' willingness, (2) ability, and (3) motivation. The results report that teachers' willingness in implementing full-day school is at $77.20 \%$ (good). Furthermore, the percentages on the ability and motivation are at $72.67 \%$ (good) and $69.71 \%$ (sufficient) respectively. The data distribution on the scope of willingness is $80.85 \%$ (good), $76.79 \%$ (good), and $77.20 \%$ (good) for teachers' enthusiasm, confidence, and enjoyment correspondingly. In the range of motivation, it is reported that teachers' knowledge is at $72.30 \%$ (good) and skill is at $73.03 \%$ (good). The statistical reports on the aspects of motivation, such as physical working conditions, social conditions, and individual needs, are at $76.68 \%, 65.71 \%$ (sufficient), and $66.75 \%$ (sufficient) respectively. These results suggest evaluation on the implementation policy of full-day school in Gorontalo regency.
\end{abstract}

Keywords: Teachers readiness, full-day school, elementary school.

\section{INTRODUCTION}

Education in elementary school is a determining factor to produce students with good characters and morality. This is due to the length of time stages that must be passed in elementary school education that is for six years or longer than the stage of other formal education. At this level, students will learn a variety of things ranging from reading, writing, arithmetic, knowing the science of religion, natural and social sciences in an effort to develop aspects of students' knowledge, skills, religious, intellectual, character, moral and emotional.

The education curriculum of elementary school is currently experiencing significant dynamics of change, from education unit level curriculum, curriculum 2013, to the implementation of full-day school program. As well as changes to the curriculum, at the beginning of the implementation, the implementation of full-day school program is still being debated, especially among teachers.

In terminology, the full-day school program implies an educational program that implements a full day learning by integrating an intensive teaching system by adding hours of lessons for the deepening of subject matter as well as self-development and creativity. The main thing in full-day school is setting the subject schedule and deepening ${ }^{1}$. The full-day school program is a school program that is partly used for learning programs that are informal, not rigid, fun for students and require creativity and innovation from teachers.

Teachers are an important element in the program development and implementation of curriculum as well as variables that helped determine the implementation of the national education system at a school. Teachers are the dominant element as the executor of learning activities in the classroom. Teachers are required to carry out learning in accordance with the development of the curriculum. In addition, teachers are required to understand the characteristics of students, so that teachers can apply character education spontaneously in every learning process so that students can meet the attitude competence.

It is not easy to prepare the ideal teacher to implement a full-day school program in a short time. Need to change the pattern of learning that requires readiness of teachers originally only served to teach a teacher who is able to encourage students to be more active and creative as desired in the curriculum or full-day school program. This is an obstacle for teachers because not all teachers are ready and able to do in a short time, while the implementation of the program and its learning tools have not been prepared in advance.

Gorontalo regency is one of the areas that has implemented a full-day school program. As an educational pilot project area, the implementation of full-day school program, especially in elementary schools, is still experiencing polemics. Based on 
interviews with several teachers, they are still confused with the technical implementation of the program. A teacher said that he feels there is a concern in the implementation of the program. That concern is devoted to the problem of readiness of teachers in the implementation of full day school program.

The concept of "teacher readiness" is a phrase consisting of two words of "readiness" and "teacher". The word readiness comes from the word ready which means attitude or "already willing" 2 . Teacher's understanding is formally written in Undang-undang No. 14 of 2005 is defined as "professional educator with the main task of educating, teaching, guiding, directing, training, assessing and evaluating students in early childhood education on formal education, primary education and secondary education". So the teachers' readiness can be interpreted as an attitude of willingness to engage in the task of educating, teaching, guiding, directing, training, assessing, and evaluating students.

The concept of teacher readiness can be derived from the theory of worker maturity and the theory of worker productivity in an organization. Hersey and Blanchard (2004) put forward the concept of worker maturity as a readiness that is the ability and willingness of people to assume responsibility for directing their own behavior ${ }^{3}$. The concept of maturity, according to Hersey and Blanchard contains two dimensions: work maturity (ability) and psychological maturity (willingness). In terms of job maturity is associated with the knowledge and skills of people to do something. While psychological maturity is associated with the willingness or motivation of people to do something.

Another theory relevant to the concept of teacher readiness is the theory of work productivity of employees or performance of employees. Sutermeister (1999) sees work productivity or employee performance in terms of human size of work. In this case there are two dimensions in $\mathrm{man}^{4}$. Work that becomes an essential ingredient for productivity or good worker performance, namely ability, and motivation. Performance of teachers depending on ability and motivation.

Thus it can be concluded that the readiness of teachers in this study, teacher readiness associated with the implementation of full-day school program is as teachers' willingness, motivation and ability. It can be concluded that the dimensions of teachers' readiness can be measured according to the performance concept model proposed by Sutermeister (1999) and Hersey and Blanchard (2004) as follows; (1) the willingness dimensions can be determined by observing the behavior of enthusiasm, fun, and confidence; (2) the ability dimension that includes knowledge and skill; and (3) the dimensions of motivation which include the physical condition of the job, the social conditions of work, and the individual needs ${ }^{3}, 4$.
Teachers' readiness in the implementation of full-day school program depends on the interpretation of teachers to the perception of the program. Readiness of teachers can be interpreted as an attitude of willingness to engage in the task of educating, teaching, guiding, directing, training, assessing, and evaluating students.

This descriptive research aims at describing elementary school teachers' readiness in the implementation of full-day school in Gorontalo regency. The teachers' readiness is devoted to the dimensions of willingness, the ability, and the dimensions of motivation covering (1) the physical condition of the job, (2) the social conditions of the work, and (3) the individual needs.

\section{RESEARCH METHODS}

This study is a descriptive study through a survey conducted in Even Semester of the 2016/2017 Lesson Year, precisely in May and June of 2017. Data on the readiness of elementary school teachers in the implementation of full-day school program is taken using a questionnaire. Respondents of 100 primary school teachers were randomly assigned to several schools from several districts in Gorontalo regency. Indicators of this study include (1) the willingness of teachers (Willingness), (2) the ability of teachers (ability) and (3) teacher motivation.

The data were analyzed using descriptive quantitative analysis technique in the form of average and percentage. The results of the data analysis were then compared with the criteria for determining the level of readiness of elementary school teachers in the implementation of full day school program. The criteria used refers to Permendiknas Number 74 of 2011 on teacher performance Assessment as listed in Table 1 as follows.

Table 1. Criteria for Determining Level of Primary School Teacher Readiness in Full Day School Program Implementation

\begin{tabular}{cc}
\hline Achiefment Score & Category \\
\hline $0,00-55,00 \%$ & Less \\
$55,01-70,00 \%$ & Sufficient \\
$70,01-85,00 \%$ & Good \\
$85,01-100 \%$ & Very good \\
\hline
\end{tabular}

\section{RESULTS AND DISCUSSION}

Implementation of full-day school program is promising many things such as learning opportunities more students and teachers have the opportunity to add material beyond the curriculum content. Implementation of learning in full-day school starting from morning until afternoon routinely in accordance with the program at each level of education. In full day school also the institution is free to set its own 
subject schedule by keeping referring to the national standard of time allocation as a minimum standard and appropriate subject weight and coupled with other deepening models.

Research has been conducted to collect teacher readiness data in implementing full-day school program. The data includes, first is the dimension of the willingness of the teacher can be determined by observing the teacher's behavior in matters such as enthusiasm, fun, and confidence. The second is the ability dimension which includes knowledge and skill. Third, the dimensions of motivation that includes the physical condition of work, social conditions of employment, and individual needs.

\subsection{Description of Teachers' Readiness Viewed from the Dimension of Willingness}

Based on the results of the study, it is found that the readiness of teachers in the implementation of full day school program dimension of willingness is good with the average score of $77.20 \%$ with the score of each aspect include enthusiasm, confidence and enjoyment are $80.85 \%, 76.79 \%$ and $73.96 \%$. More details can be seen in Tables 2, 3 and 4 .

Table 2. Teacher enthusiasm for full day school program implementation

\begin{tabular}{|c|c|c|c|}
\hline No & Rated aspect & $\begin{array}{c}\text { Score } \\
(\%)\end{array}$ & Category \\
\hline 1 & $\begin{array}{l}\text { Teachers have responded } \\
\text { positively of full-day } \\
\text { school program }\end{array}$ & 87.75 & Very Good \\
\hline 2 & $\begin{array}{l}\text { Teachers already know th } \\
\text { background of full-day } \\
\text { school program } \\
\text { implementation }\end{array}$ & 82.50 & Good \\
\hline 3 & $\begin{array}{l}\text { Teachers already know } \\
\text { the purpose of } \\
\text { implementing the full- } \\
\text { day school program }\end{array}$ & 78.25 & Good \\
\hline 4 & $\begin{array}{l}\text { Teachers have learned } \\
\text { the technical manual of } \\
\text { full-day school program }\end{array}$ & 72.25 & Good \\
\hline \multirow[t]{2}{*}{5} & $\begin{array}{l}\text { Teachers have been } \\
\text { excited for full-day } \\
\text { school program }\end{array}$ & 83.50 & Good \\
\hline & Average & 80.85 & Good \\
\hline
\end{tabular}

Table 2 shows that teachers have good enthusiasm for full-day school program implementation. Teacher very warmly welcomed the implementation of the program. But there are some important things to note, there are some teachers who do not know the background, the purpose of implementation of the program. There are even teachers who have never learned the technical guidance of the program's implementation.
Table 3. Teacher confidence in the implementation of fullday school program

\begin{tabular}{|c|c|c|c|}
\hline No & Rated aspect & $\begin{array}{c}\text { Score } \\
(\%)\end{array}$ & Category \\
\hline 1 & $\begin{array}{l}\text { Teachers already feel } \\
\text { confident with the successful } \\
\text { of full day school program }\end{array}$ & 74.75 & Good \\
\hline 2 & $\begin{array}{c}\text { Teachers have felt confident } \\
\text { that full day school programs } \\
\text { can improve students' } \\
\text { character }\end{array}$ & 84.00 & Good \\
\hline 3 & $\begin{array}{l}\text { Teachers are ready to be } \\
\text { good role models for students } \\
\text { while they are at school }\end{array}$ & 83.00 & Good \\
\hline 4 & $\begin{array}{l}\text { The state of school facilities } \\
\text { and infrastructure has } \\
\text { supported the full day school } \\
\text { program }\end{array}$ & 65.25 & Sufficient \\
\hline 5 & $\begin{array}{l}\text { The state of teachers in } \\
\text { schools has supported the full } \\
\text { day school program. }\end{array}$ & 75.75 & Good \\
\hline 6 & $\begin{array}{l}\text { Schools evaluate the program } \\
\text { of full-time school program } \\
\text { implementation on a regular } \\
\text { basis }\end{array}$ & 78.00 & Good \\
\hline & Average & 76.79 & Good \\
\hline
\end{tabular}

In table 3 , it is known that teachers feel confident with the successful implementation of full day school program, especially in improving the character of students. Teachers have also been prepared to be role models while at school. But barriers will be the teacher beliefs hindered by the presence of existing facilities and infrastructure in schools.

Table 4. Teacher's enjoyment of full-day school program implementation

\begin{tabular}{|c|c|c|c|}
\hline No & Rated aspect & $\begin{array}{l}\text { Score } \\
(\%)\end{array}$ & Category \\
\hline 1 & $\begin{array}{l}\text { Teachers have enjoyed his } \\
\text { role from beginning to end } \\
\text { up learning activities }\end{array}$ & 80.75 & Good \\
\hline 2 & $\begin{array}{l}\text { Teachers have to feel } \\
\text { happy all day with my } \\
\text { students. }\end{array}$ & 79.00 & Good \\
\hline 3 & $\begin{array}{c}\text { Teachers has been tired all } \\
\text { day at school }\end{array}$ & 62.75 & Sufficient \\
\hline 4 & $\begin{array}{l}\text { Teachers have provided } \\
\text { motivation to fellow } \\
\text { teachers at school }\end{array}$ & 74.00 & Good \\
\hline 5 & $\begin{array}{l}\text { Teachers have had time to } \\
\text { channel hobbies since the } \\
\text { implementation of the full- } \\
\text { day school program }\end{array}$ & 68.75 & Good \\
\hline \multirow[t]{2}{*}{6} & $\begin{array}{c}\text { Teachers have participated } \\
\text { in race events aimed at } \\
\text { educators }\end{array}$ & 78.50 & Good \\
\hline & Average & 73.96 & Good \\
\hline
\end{tabular}

The teachers enjoy their role during the full-day school program during the semester. But there are 
some obstacles related to the enjoyment of the teacher, among them felt more tired and the time for his hobby felt reduced. This is shown in Table 4.

\subsection{Description of Teachers' Readiness Viewed from the Dimension of Ability}

Successful implementation of full day school program depends also on the ability of teachers. Teachers should be ready in their knowledge and skills. From the research results obtained that the readiness of teachers in terms of knowledge and skills is good with a score of each is $72.30 \%$ and $73.03 \%$.

Table 5. Teacher's knowledge of full day school program

\begin{tabular}{|c|c|c|c|}
\hline No & Rated aspect & $\begin{array}{c}\text { Score } \\
(\%)\end{array}$ & Category \\
\hline 1 & $\begin{array}{l}\text { Teachers have attended the } \\
\text { socialization of full day } \\
\text { school program }\end{array}$ & 69.50 & Sufficient \\
\hline 2 & $\begin{array}{l}\text { The teacher has done the } \\
\text { things that have been } \\
\text { obtained in the socialization } \\
\text { of the full day school } \\
\text { program }\end{array}$ & 73.75 & Good \\
\hline 3 & $\begin{array}{l}\text { Teachers have attended } \\
\text { technical training activities } \\
\text { on the implementation of } \\
\text { full day school program. }\end{array}$ & 64.25 & Sufficient \\
\hline 4 & $\begin{array}{l}\text { Teachers have prepared the } \\
\text { planning, materials or } \\
\text { teaching materials for the } \\
\text { implementation of the full } \\
\text { day school program }\end{array}$ & 75.75 & Good \\
\hline 5 & $\begin{array}{c}\text { Teachers have followed the } \\
\text { activities in the framework } \\
\text { of self-development }\end{array}$ & 78.25 & Good \\
\hline & Average & 72.30 & Good \\
\hline
\end{tabular}

In table 5, it appears that, teachers have attended technical training activities about the implementation of full-day school program, although there are still teachers who have never followed the socialization activities about the program. Another evidence that teachers are ready from the knowledge aspect is that teachers have prepared their planning for full day school program implementation.

Table 6. Teacher skills about full day school program

\begin{tabular}{|c|c|c|c|}
\hline No & Rated aspect & $\begin{array}{c}\text { Score } \\
(\%)\end{array}$ & Category \\
\hline 1 & $\begin{array}{l}\text { Teachers have } \\
\text { completed daily } \\
\text { learning programs }\end{array}$ & 69.75 & Sufficient \\
\hline 2 & $\begin{array}{l}\text { Teachers have had the } \\
\text { talent to be a teacher }\end{array}$ & 82.25 & Good \\
\hline 3 & $\begin{array}{l}\text { Teachers has been } \\
\text { educating earnestly }\end{array}$ & 89.00 & Good \\
\hline 4 & Teachers have the & 69.50 & Sufficient \\
\hline
\end{tabular}

\begin{tabular}{|c|c|c|c|}
\hline & ability to build scout & & \\
\hline 5 & $\begin{array}{l}\text { Teachers already have } \\
\text { the ability to build } \\
\text { junior red cross youth } \\
\text { Teachers have the }\end{array}$ & 67.50 & Sufficient \\
\hline 6 & $\begin{array}{l}\text { ability to build art } \\
\text { activities }\end{array}$ & 75.75 & Good \\
\hline 7 & $\begin{array}{l}\text { Teachers already have } \\
\text { religious abilities }\end{array}$ & 75.50 & Good \\
\hline \multirow[t]{2}{*}{8} & $\begin{array}{l}\text { Teachers remain } \\
\text { energetic to guide } \\
\text { extracurricular } \\
\text { activities }\end{array}$ & 55.00 & Less \\
\hline & Average & 73.03 & Good \\
\hline
\end{tabular}

The teacher's readiness constraints are in the teacher's skills to foster extra-curricular activities. This is shown in Table 6 , where only some teachers $(55.00 \%)$ feel empowered to guide the additional activities. Included are scouting ability $(69.50 \%)$ and ability to build Junior Red Cross Youth (67.5\%). Although the teacher has been educating earnestly, but the teacher is just sufficient to complete the learning program every day.

\subsection{Description of Readiness Teachers Viewed from the Dimension of Motivation}

Teacher's motivation greatly determines teacher performance. Motivation also affects teacher readiness. There are several aspects studied related to motivation, namely the physical condition of work, social conditions of work, and individual needs. The results of research on these aspects can be seen in Tables 7, 8 and 9 .

Table 7. Physical condition of work in the implementation of full-day school program

\begin{tabular}{|c|c|c|c|}
\hline No & Rated aspect & $\begin{array}{c}\text { Score } \\
(\%)\end{array}$ & Category \\
\hline 1 & $\begin{array}{l}\text { Teachers had prepared the } \\
\text { lesson the day before }\end{array}$ & 71.75 & Good \\
\hline 2 & $\begin{array}{l}\text { Teachers have set up } \\
\text { learning tools }\end{array}$ & 78.75 & Good \\
\hline 3 & $\begin{array}{l}\text { Teachers have been } \\
\text { conducting students' } \\
\text { attitude assessment every } \\
\text { day of the full-day school } \\
\text { program }\end{array}$ & 79.00 & Good \\
\hline 4 & $\begin{array}{l}\text { Teachers have remained } \\
\text { healthy since the full day } \\
\text { school }\end{array}$ & 64.50 & Sufficient \\
\hline 5 & $\begin{array}{l}\text { Teachers have come and } \\
\text { go home on time }\end{array}$ & 80.75 & Good \\
\hline 6 & $\begin{array}{l}\text { Teachers have to bring } \\
\text { food from home }\end{array}$ & 79.00 & Good \\
\hline \multirow[t]{2}{*}{7} & $\begin{array}{l}\text { Teachers have performed } \\
\text { well during the full day } \\
\text { school program }\end{array}$ & 83.00 & Good \\
\hline & Average & 76.68 & Good \\
\hline
\end{tabular}


The physical condition of teachers' work in full day school program implementation is good $(76.68 \%)$. The teacher had prepared the lesson the day before. Master has come and gone on time. Teachers have also performed well during the full day school program. But there are some teachers who experience health problems since the implementation of full-day school program.

Table 8. Social conditions of teacher work in full day school program implementation

\begin{tabular}{|c|c|c|c|}
\hline No & Rated aspect & $\begin{array}{c}\text { Score } \\
(\%)\end{array}$ & Category \\
\hline 1 & $\begin{array}{l}\text { Teachers have been } \\
\text { able to maintain their } \\
\text { emotional stability } \\
\text { while dealing with } \\
\text { students }\end{array}$ & 84.00 & Good \\
\hline 2 & $\begin{array}{l}\text { Teachers have been } \\
\text { bored with activities } \\
\text { during the full day } \\
\text { school program }\end{array}$ & 38.50 & Good \\
\hline 3 & $\begin{array}{l}\text { Teachers have worked } \\
\text { with fellow teachers at } \\
\text { school }\end{array}$ & 85.75 & Good \\
\hline 4 & $\begin{array}{l}\text { When my emotions are } \\
\text { unstable, the teacher } \\
\text { has chosen not to deal } \\
\text { with the students }\end{array}$ & 56.00 & Sufficient \\
\hline 5 & $\begin{array}{l}\text { Teacher has wreaked } \\
\text { out my frustration on } \\
\text { the students. }\end{array}$ & 25.75 & Less \\
\hline 6 & $\begin{array}{l}\text { Parents of students } \\
\text { (school committees) } \\
\text { have supported the } \\
\text { implementation of the } \\
\text { full day school } \\
\text { program }\end{array}$ & 82.00 & Good \\
\hline \multirow[t]{2}{*}{7} & $\begin{array}{l}\text { Teachers have felt } \\
\text { helpful and motivated } \\
\text { by the principal's } \\
\text { leadership }\end{array}$ & 88.00 & Good \\
\hline & Average & 65.71 & Sufficient \\
\hline
\end{tabular}

During the full-day school program, teachers did not feel bored with their activities, Teachers have been able to maintain their emotional stability while dealing with students. Teachers have worked with fellow teachers and parents. Teachers are also able to control their emotions towards the students. In addition, teachers have felt helpful and motivated by the principal's leadership.
Table 9. Individual needs in full day school program implementation

\begin{tabular}{|c|c|c|c|}
\hline No & Rated aspect & $\begin{array}{l}\text { Score } \\
(\%)\end{array}$ & Category \\
\hline 1 & $\begin{array}{l}\text { Teachers have time with } \\
\text { my family at home }\end{array}$ & 63.75 & Sufficient \\
\hline 2 & $\begin{array}{l}\text { The teacher felt that the } \\
\text { salary of the teacher did } \\
\text { not match his obligations } \\
\text { and responsibilities } \\
\text { during the full day } \\
\text { school program }\end{array}$ & 63.25 & Sufficient \\
\hline & $\begin{array}{l}\text { Teachers have felt } \\
\text { comfortable at the school }\end{array}$ & & \\
\hline 3 & $\begin{array}{l}\text { since the implementation } \\
\text { of full day school } \\
\text { program. }\end{array}$ & 81.25 & Good \\
\hline 4 & $\begin{array}{l}\text { School has facilitated the } \\
\text { teacher, if there is a } \\
\text { sudden need. }\end{array}$ & 77.75 & Good \\
\hline 5 & $\begin{array}{l}\text { Schools provide special } \\
\text { rooms for teachers to rest } \\
\text { in school }\end{array}$ & 64.25 & Sufficient \\
\hline \multirow[t]{2}{*}{6} & $\begin{array}{l}\text { Teachers have felt the } \\
\text { time is much consumed } \\
\text { since the implementation } \\
\text { of the full day school } \\
\text { program }\end{array}$ & 50.25 & Sufficient \\
\hline & Average & 66.75 & Sufficient \\
\hline
\end{tabular}

Obstacles teachers in the implementation of this program is related to the needs of individuals. Master feels more time consumed and they have less time with their family. The teacher felt that the salary of the teacher was not in line with his obligations and responsibilities. So even the special room for teachers to rest in school is still felt less. This can be seen in Table 9.

\section{Discussion}

Implementation of full-day school program in terms of institutional, leadership, and management refers to the concept of promoting the glory of morality and academic achievement. In implementing the full day school system, it is necessary to prepare teachers to plan the education according to the purpose of the program implementation.

In Indonesia, the full day school program was first formally initiated by Muhadjir Effendy as the Minister of Education and Culture on July 27, 2016. Many people think that this full day school system is a new system and first applied in Indonesia. Though such a system has actually been embraced for a long time by the existing educational system in Indonesia, such as the existing education system in boarding school or all day school. Similarly, the existing education system in international schools that implement the boarding school system, where students learn a full day at school and live in dorms ${ }^{5}$. Education is a conscious and planned effort to create an atmosphere of learning and learning process so 
that students can actively develop The potential of self to have spiritual spiritual strength, self-control, personality, intelligence, skill, and noble character ${ }^{6}$.

Implementation of full-day school programs certainly can not be separated from various obstacles or inhibiting factors. Based on the results of research, obtained information that there are several inhibiting factors are aspects of facilities and infrastructure as well as aspects of individual needs of teachers. Facilities and infrastructure is a vital part that supports the success of all educational activities in schools. While teachers who are required to accompany students all day at school become overwhelmed in understanding the ability and character of students.

The teacher is burdened with a target to manage an interesting and enjoyable teaching-learning atmosphere so that students do not feel bored and remain enthusiastic about receiving lessons ${ }^{7}$. To be able to meet this, the readiness of the teacher is very important. That readiness can not be limited to times of change, rather, it is closely related to the total experiences of teachers on their job. As a result, for a more effective management of teachers' attitudes towards change leadership needs to hold a broader temporal and contextual understanding rather than demonstrating limited interventions during times of change ${ }^{8}$.

Furthermore, if it is studied more deeply in each dimension to see up to the indicators it has been obtained information of any indicators that are categorized as excellent, good, enough, and less (Figure 1). The aspect of each dimension that belongs to enough category and less meaning is a weakness that needs to get attention, which then need to be addressed and given a solution for full day school program implementation can run as expected. From the exposure of research results, generally can get the picture data as in Figure 1.

From the result of data analysis, generally give picture that readiness of elementary school teacher in Kabupaten Gorontalo especially in the implementation of full-day school program included in good category (73.19\%). In Figure 1 it appears that the teacher's enthusiasm is not balanced with the social conditions of the work and the individual needs of the teachers themselves who are in enough categories. Such results are certainly not ideal still needs to be improved again.

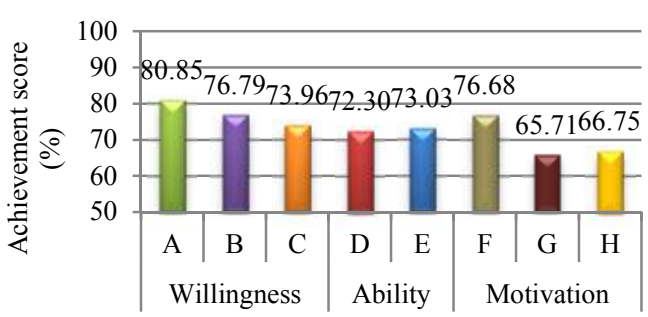

Figure 1. Graph of teacher readiness in the implementation of full-day school program in elementary school (A: enthusiasm, B: pleasure, C: belief, D: knowledge, E: skill, F: physical condition of job, G: social condition of work and $\mathrm{H}$ : Individual needs)

With the fundamental changes in the program and the timing of the learning activities in the school takes time for the teacher to adjust to those changes. Factors that are likely to cause teacher readiness are still not optimal are as follows: 1) not all teachers have followed technical guidance or training related to the implementation of full day school program; 2) limited facilities and supporting infrastructure; 3) lack of fulfillment of individual needs of teachers that cause teacher motivation to decrease, 4) lack of teacher skills in extracurricular field, such as scouts, Junior Red Cross Youth and arts, and 5) the implementation of a hasty and somewhat forced fullschool program without being accompanied with resource setup. These things need attention to be improved for the implementation of full-day school program in the future better.

\section{CONCLUSIONS AND SUGGESTIONS}

Full day school is defined as a system that requires the learning process in school longer or full day, in order to create quality of quality education and create students character, independent, creative, and noble character. The readiness of elementary school teachers in Kabupaten Gorontalo especially in the implementation of full day school program included in good category $(73.19 \%)$. To improve teachers' readiness, synergy and comprehensive efforts must be made by stakeholders by teachers, principals, supervisors, as well as by relevant local and central government officials. 


\section{REFERENCES}

[1] Baharuddin. Pendidikan dan Psikologi Perkembangan. Yogyakarta: Ar-Ruzz Media; 2014.

[2] Alwi, Hasan. Kamus Besar Bahasa Indonesia. Jakarta: Balai Pustaka; 2007.

[3] Hersey dan Blanchard, Management of Organizational Behavior: Utilizing Human Resources. New Jersey: Prentice Hall; 2004.

[4] Sutermeister, R.A, People and Producktivity. Toronto, Mc. Graw Hill Book.Co; 1999.

[5] Pakar, P. Sejarah Sistem Full Day School dan Penerapannya. https://pendapatpakar.com; 2016.

[6] Sjarkawi. Pembentukan Kepribadian Anak. Jakarta: PT Bumi Aksara. 2006.

[7] Pramawati, D.V. Keunggulan dan Kelemahan Sistem (FDS). http://www.informasiguru.com; 2016.

[8] Beyciogl, Kadir, Mehmet Sinjar and Jalal Teyy of Ugurlu. Readiness of teachers for change in schools.

http://dx.doi.org/10.1080/13603124.2015.

1023361; 2015. 